\title{
Optimization of Biological Oxygen Demand Reduction from Textile Effluent by Oxidation
}

\author{
Sunil k. Sharma ${ }^{1}$, Neetu Sharma ${ }^{2}$, Amrita Shrivastava ${ }^{3}$ \\ ${ }^{I}$ Department of Chemistry and Environment Engineering. Jagannath University, India \\ ${ }^{2}$ Department of Chemistry and Environment Engineering. University of Rajasthan, India \\ ${ }^{3}$ Department of environment engineering, Jagannath University, India
}

\begin{abstract}
The textile dyeing and printing units in Sanganer town, Jaipur, Rajasthan, India. Discharge a huge volume of mostly untreated textile dye wastewater (10,000-15,000kl/day) into various pools and drain adjoining the textile printing units. A number of azo dyes are used in textile printing industries, As a result. The textile waste waters are loaded with them, along with other chemicals used during printing and fixing of dyes on cloth. The main cause of generation of this effluent is the use of huge volume of water either in the actual chemical processing or during re-processing in preparatory, dying, printing and finishing, which is responsible for higher biological oxygen demand(BOD), so currently these industries facing significant challenges, associated mainly with Environmental legislation because BOD removal reduction of could not be achieved, discharge effluent's concentration is too high from discharge limit prescribed by Rajasthan State Pollution Control Board, The objective of study is physiochemical analysis of water in study area and the BOD reduction in textile wastewater. For BOD reduction three oxidizers Hydrogen peroxide, Calcium hypochlorite, Potassium dichromate was used to compare their treatment efficiency at different temperature, dosages and retention time.
\end{abstract}

Keywords: Textile industry, Textile effluent, BOD reduction, Oxidizing reagents, Discharge limit.

\section{Introduction}

Textile is an important industry for Rajasthan, representing over 20 percent of the investment made to the state. Sanganer is located about $15 \mathrm{~km}$ out of Jaipur, the state capital population of more than two million people. The famous art of printing developed in Sanganer during the $18^{\text {th }}$ century and attained its peak in the $19^{\text {th }}$ century. There lent less efforts and innovative techniques established this art over the world. Until the latter half of the $19^{\text {th }}$ century, with the exception off new mineral colors like Nilathotha $\left(\mathrm{CuSO}_{4}\right)$ and tin chloride $\left(\mathrm{SnCl}_{2}\right)$, all dyes used was vegetable or animal in origin .Now-a-days, this natural dyes to have been almost completely replaced by synthetic dyes. There are estimated to be around 500 block and screen printing units in Sanganer. According to be port of United Nations industrial development organization, the export from this sector is of Rs200-300 cores per annum. Thousands of local people are employed in these industries, and their whole families are dependent upon this trade. Environmental problems within the textile industry are mainly caused by discharges of waste water. Textile industry is categorized as a red industry, Textile processing employs a variety of chemicals, depending upon the nature of the raw material and product .Textile finishing industry uses amounts of water, mainly because of washing operations, fig 1 . Shown the $\%$ water consumption in textile industry.

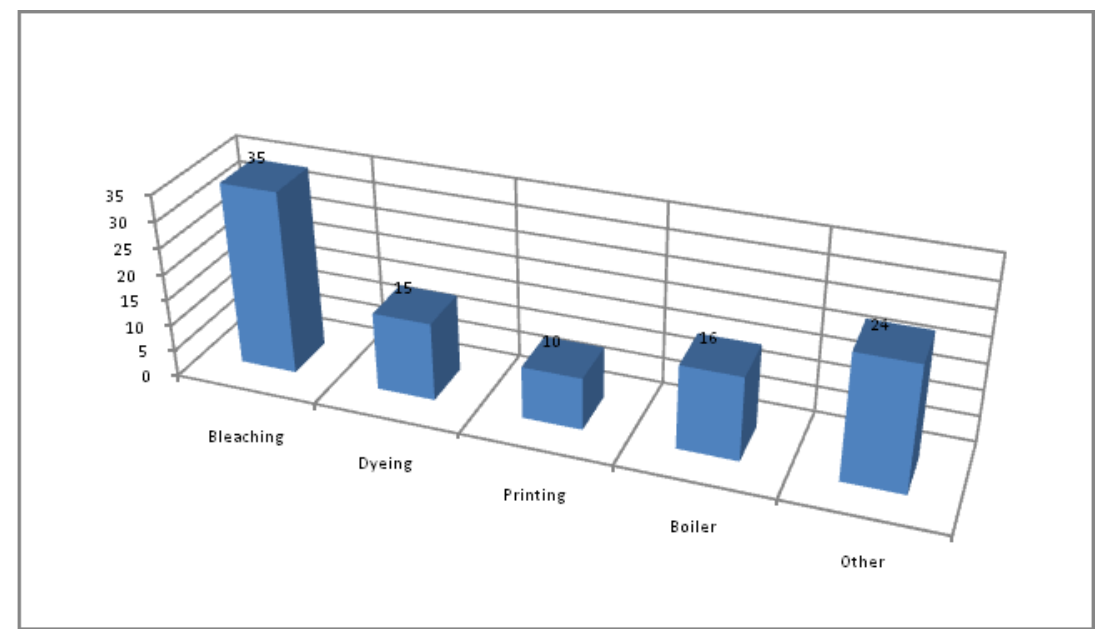

Fig. 1. \% water consumed during wet processing in textile industry 
Therefore, processing waste water have high- flow rates textile waste water contains substantial pollution loads in terms of COD, BOD, TSS, TDS and heavy metals. The value of these parameters is very high as compared against the values in Bureau of Indian standards (BIS) set by the government of India.

Characteristics of textile waste water are prerequisite for the investigation of treatment options. Ecological and toxicological problems due to the discharge of waste water from Sanganer textile industries in local drainage (Amani Shah Ka Nallah) have been one of the most important water pollution problems within this area. Studies have clearly indicated that the industrial effluents, which are directly discharged into the Amani Shah Ka Nallah, drainage contained highly mutagenic compounds. These compounds also contaminate the surface and even ground water, thereby, making it unfit for irrigation and drinking, Sanganer, a suburb of Jaipur is no exception to this. Direct dumping of industrial waste water in and around industrial areas causes the transfer of pollutants into the environment (Baslas and Singh, 1984). It can also lead to significant deterioration in the aesthetic value of down stream waters. The disposal fun treated textile waste water in Sanganer has contaminated ground water with heavy metals such as $\mathrm{Zn}, \mathrm{Ni}, \mathrm{Cr}, \mathrm{Cd}, \mathrm{Pb}, \mathrm{Cu}$, and $\mathrm{Fe}$, which is reported in more than permissible limits by the Rajasthan State Pollution Control Board, Jaipur and other workers (Manivasakam, 1987; Usha,1989; Khanetal.,1995;Sharmaetal.,1999). The objectives of this study are to analyze the physicochemical properties of water (adjoining the textile effluent) which will help in identification of environmental impacts due to release of effluents and other wastes and treatment methods .In this study, we used three different Oxidants Hydrogen peroxide $\left(\mathrm{H}_{2} \mathrm{O}_{2}\right)$, Calcium Hypochlorite $\left[\mathrm{Ca}(\mathrm{OCl})_{2}\right]$, potassium dichromate $\left(\mathrm{K}_{2} \mathrm{Cr}_{2} \mathrm{O}_{7}\right)$ to reduce the $\mathrm{BOD}$ of industrial waste water.

\section{Study Area And Sampling}

Sanganer town $\left(26^{\circ} 49^{\prime}-26^{\circ} 51^{\prime} \mathrm{N}\right.$ latitude and $75^{\circ} 46^{\prime}-75^{\circ} 50^{\prime} \mathrm{E}$ longitude) lies about $16 \mathrm{~km}$ south of Jaipur city, the Rajasthan state capital in India that has a population of more than two million people. The total area of Sanganer is about $635.5 \mathrm{Sq}$. km out of which 12.9 Sq. km comprises the urban area.

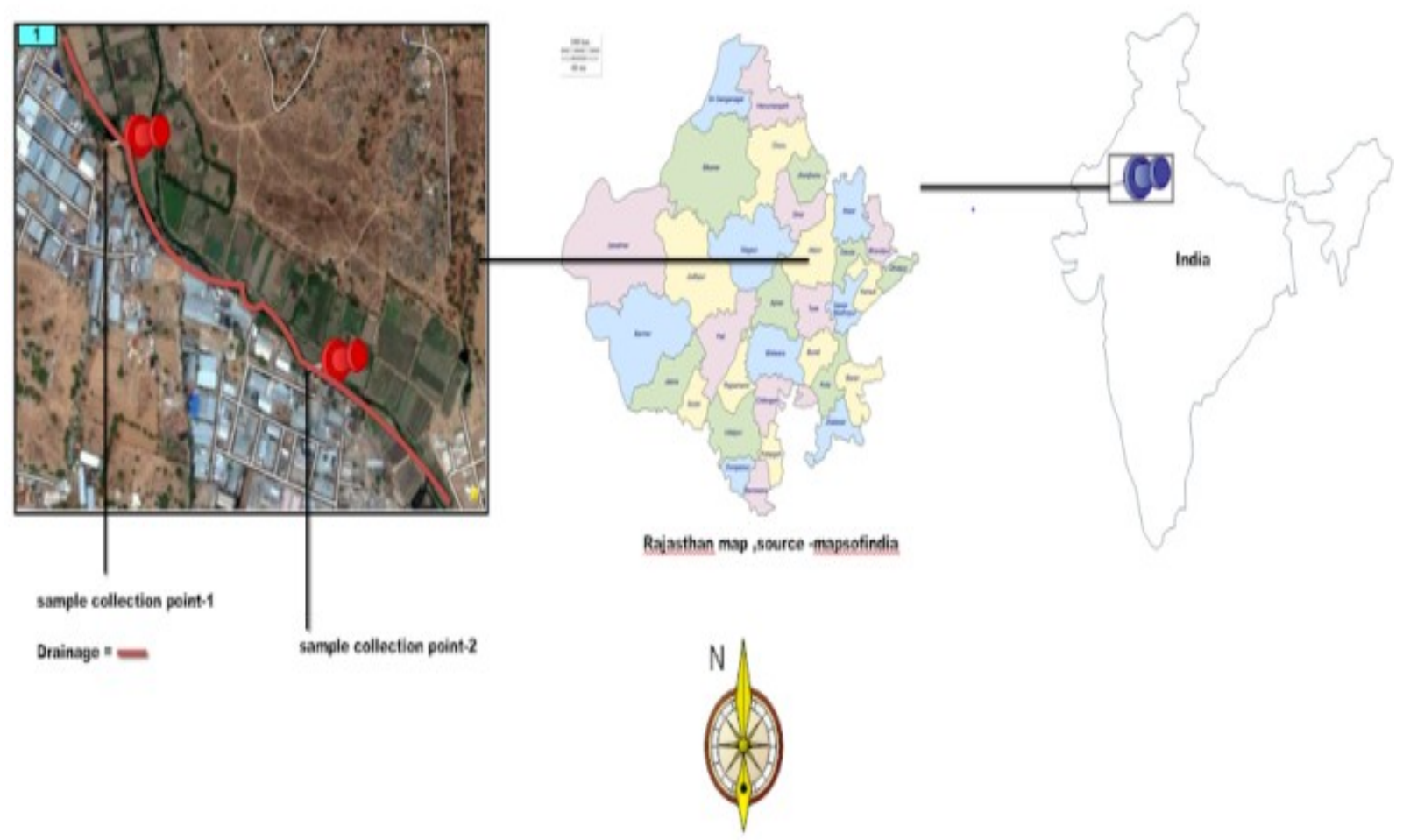

Fig. 2. Satellite view of sanganer textile industry area and effluent drainage (Jaipur, Rajasthan.)Indicating sampling points (post monsoon August 2012)

For this purpose two samples were collected during March 2012 (pre-monsoon) to August ,2012(postmonsoon)in good quality polyethylene bottles of one-litre capacity. Sampling has been carried out without adding any preservatives in well-rinsed bottles from different area of Sanganer and compares the BOD with the standards of water prescribed by state pollution and central board of Jaipur, Rajasthan, (India) as shown in fig.3 


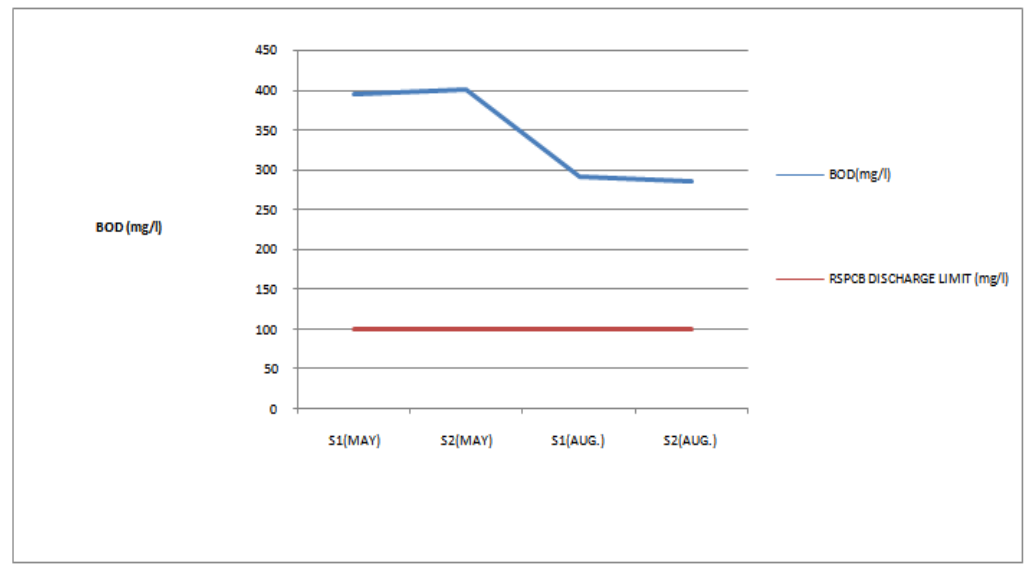

Fig.3. BOD analysis of sample (S1 and S2 collected during pre-monsoon and post monsoon), shown higher than the RSPCB (Rajasthan state pollution control board) discharge limit for textile and dyeing industry.

\section{Material And Method}

\subsection{Physico-chemical analysis of sample water}

The effluent samples were analyzed for $\mathrm{pH}$, electrical conductivity (EC), total dissolved solids (TDS) ,biological oxygen demand (BOD), calcium and magnesium hardness, cations $\left(\mathrm{Na}^{+}, \mathrm{K}^{+}\right)$and anions $\left(\mathrm{Cl}^{-}\right)$. Physicochemical Parameters of water were analyzed by standard methods (APHA, 1992).

Table 1: Physico-chemical properties of various effluent samples

\begin{tabular}{|c|c|c|c|c|c|c|c|c|}
\hline \multirow{2}{*}{ Period } & \multirow{2}{*}{$\begin{array}{l}\text { Sample } \\
\text { No. }\end{array}$} & \multirow[t]{2}{*}{$\mathrm{pH}$} & \multirow{2}{*}{$\begin{array}{l}\text { E.C. } \\
(\mathrm{mmhos} / \mathrm{cm})\end{array}$} & \multirow{2}{*}{$\begin{array}{l}\text { BOD } \\
(\mathrm{mg} / \mathrm{L})\end{array}$} & \multirow{2}{*}{\begin{tabular}{|l} 
TDS \\
$(\mathrm{mg} / \mathrm{L})$
\end{tabular}} & \multicolumn{2}{|c|}{$\begin{array}{l}\text { Cations } \\
(\mathrm{mg} / \mathrm{L})\end{array}$} & \multirow{2}{*}{\begin{tabular}{|l|}
$\begin{array}{l}\text { Anions } \\
(\mathrm{mg} / \mathrm{L})\end{array}$ \\
$\mathrm{Cl}-$ \\
\end{tabular}} \\
\hline & & & & & & $\mathrm{Na}+$ & $\mathrm{K}^{+}$ & \\
\hline \multirow{2}{*}{ May- 2012} & S1 & 8.6 & 3.50 & 395 & 915 & 380 & 2.4 & 170 \\
\hline & S2 & 8.7 & 3.50 & 400 & 740 & 216 & 1.56 & 285 \\
\hline \multirow{2}{*}{ August-2012 } & S1 & 7.6 & 3.84 & 290 & 705 & 305 & 3.12 & 128 \\
\hline & S2 & \begin{tabular}{|l|l}
7.9 \\
\end{tabular} & 4.55 & 285 & 585 & 595 & 1.1 & 135 \\
\hline
\end{tabular}

\subsection{Physico-chemical analysis of soil adjoining area.}

The samples of soil (adjoining the textile effluent) and effluent were collected from various sites of Sanganer region during different periods of the year (August and May 2012). The effluent samples were dark brown to black in colour and were giving pungent smell.

Table 1: Physico-chemical properties of various effluent soil samples

\begin{tabular}{|c|l|l|l|l|l|}
\hline Period & Sample No. & pH & E.C. $(\mathbf{m m h o s}) / \mathbf{c m}$ & $\mathbf{\%}$ O.M. & Cl $\mathbf{~ ( m g / ~ 1 0 0 g ) ~}$ \\
\hline \multirow{3}{*}{ May 2012} & S1 & 9.2 & 0.78 & 2.02 & 57 \\
\cline { 2 - 6 } & S2 & 8.8 & 1.03 & 0.89 & 35 \\
\cline { 2 - 6 } & S3 & 9.2 & 0.83 & 1.90 & 66 \\
\hline \multirow{2}{*}{ August 2012 } & S1 & 7.6 & 0.84 & 0.62 & 40 \\
\cline { 2 - 6 } & S2 & 8.1 & 1.20 & 0.40 & 38 \\
\hline
\end{tabular}

Here: $\mathbf{E C}=$ Electrical conductivity; $\mathbf{O C}=$ Organic carbon; $\mathbf{O M}=$ Organic matter.

\subsection{Determination of biological oxygen demand}

The BOD tests were carried out using standard procedure using a five-day BOD test. The method consists of filling with diluted and seeded sample, to overflowing, an airtight bottle of specified size and incubating it at the specified temperature for five days. Dissolved oxygen is measured initially and after incubation, and the BOD is computed from the difference between initial and final DO. Because the initial DO is determined shortly after the dilution is made, all oxygen uptake occurring after this measurement is included in the BOD measurement. Samples were diluted 15 times before the test followed by aeration to make sure enough dissolved oxygen $(7.5 \mathrm{mg} / \mathrm{l})$ will remain after five days of the test. $300 \mathrm{ml}$ standard BOD bottles were used in these tests which were incubated at $20{ }^{\circ} \mathrm{C}$ in a dark incubator. After five days, the difference in oxygen consumption was measured to estimate $\mathrm{BOD}_{5}$.

\subsection{Reduction of BOD by oxidizing reagents}

All chemicals employed in this study were analytical grade. All solutions were prepared in distilleddeionized water made on each experimental day. Glassware used in this work was soaked with HNO3 $(\sim 10 \%)$ 
for $24 \mathrm{~h}$, and rinsed with distilled-deionized water prior to drying. Batch experiments were conducted in the laboratory. In these experiments different types of oxidants such as $(33 \%)$ Hydrogen peroxide $\left(\mathrm{H}_{2} \mathrm{O}_{2}\right)$, Calcium Hypochlorite [Ca $\left.(\mathrm{OCl})_{2}\right]$ [MERCK, MB0M 600436, 30\% $\mathrm{Cl}_{2}$ ] and Potassium dichromate $\left(\mathrm{K}_{2} \mathrm{Cr}_{2} \mathrm{O}_{7}\right)$ [GR,MERCK,MC1M 610500] were used. Eight bottles were used in these tests having two of them without oxidants to check the initial BOD values, and for each oxidant, two bottles were used to check the accuracy of measurements. The $\mathrm{pH}$ of the aqueous solutions was adjusted with $1 \mathrm{M} \mathrm{H}_{2} \mathrm{SO}_{4}$ or $1 \mathrm{M} \mathrm{NaOH}$ solutions. Exact concentration was determined by standardizing them against a $0.1 \mathrm{~N}$ sodium thiosulphate solution. $50 \mathrm{ml}$ of the sample was taken in a $250 \mathrm{~mL}$ borosilicate flask, and the known amount of oxidant's solution was added. The flask contents were heated at $25^{\circ} \mathrm{C}, 50^{\circ} \mathrm{C}, 100^{\circ} \mathrm{C}$ and then solution was left for 60 minutes, after words the BOD of this treated sample was determined. Once suitable oxidant was identified, the same dosage was used with variations of $\mathrm{pH}$ from 2 to 8 and retention time in order to check the effect of $\mathrm{pH}$ and the retention time 30 and 10 minutes in BOD removal.

\section{Experimental Result Analysis}

\subsection{Effect of Retention time and temperature}

The experiments were carried out with the fixed dose of oxidants and $\mathrm{pH}$ whereas the retention time and temperature were varied from 10 to $60 \mathrm{~min}$ and $25^{\circ} \mathrm{C}$ to $100^{\circ} \mathrm{C}$ respectively, to determine the optimum value of retention time and temperature for BOD removal. The effects of different time and temperature is shown in figure 4 to 6 , the removal of BOD increase with an increase the retention time and temperature with the same amount of oxidants and $\mathrm{pH}$. It can be seen that the optimum BOD reduction at $100^{\circ} \mathrm{C}$, when temperature increased, the rate of $\mathrm{BOD}$ reduction is increased because the higher temperature facilitated the high rate of reaction, and maximum $\mathrm{BOD}$ reduction were Obtained at lesser retention time.

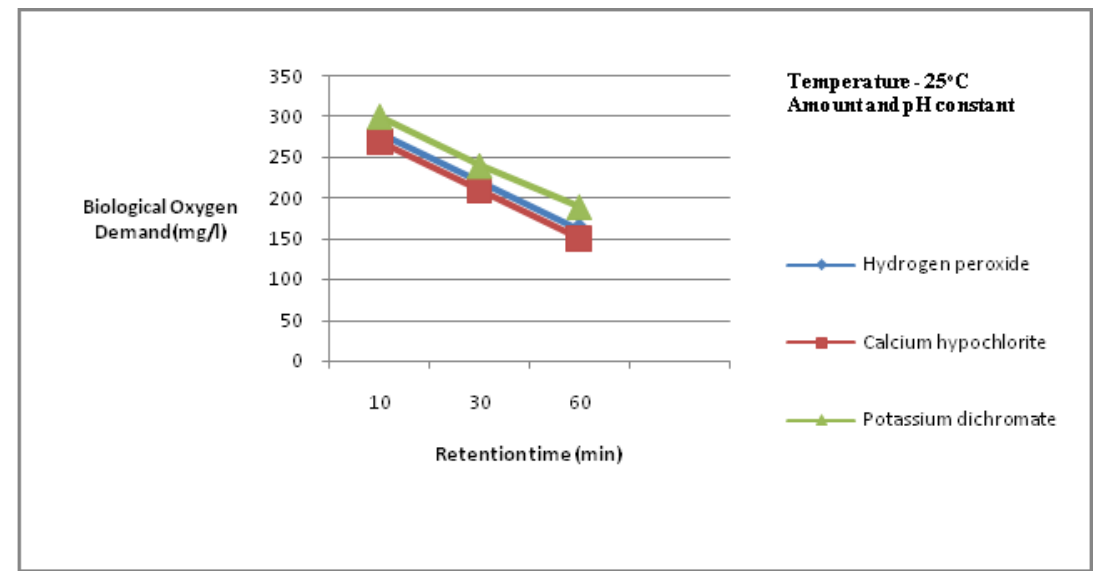

Fig. 4.Biological oxygen demand reduction at different retention time while temperature, amount and $\mathrm{pH}$ are constant ( $\mathrm{pH}-3$ to 6 , temperature $-25^{\circ} \mathrm{C}$, amount $-100 \mathrm{mg} / \mathrm{l}$ )

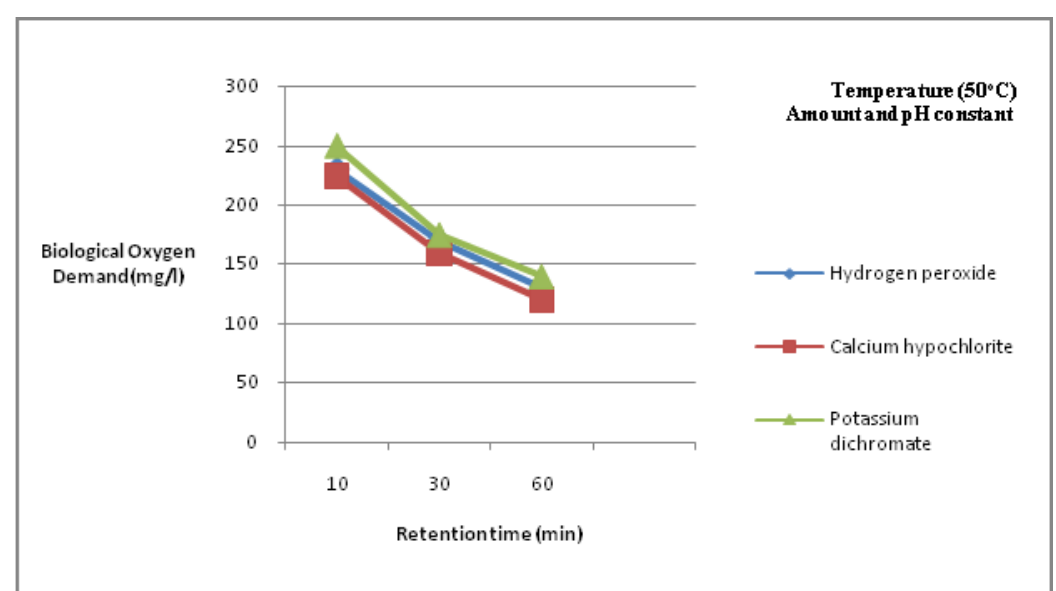

Fig. 5.Biological oxygen demand reduction at different retention time while temperature, amount and $\mathrm{pH}$ are constant (pH-3 to 6 , temperature $-50^{\circ} \mathrm{C}$, amount $-100 \mathrm{mg} / \mathrm{l}$ ) 


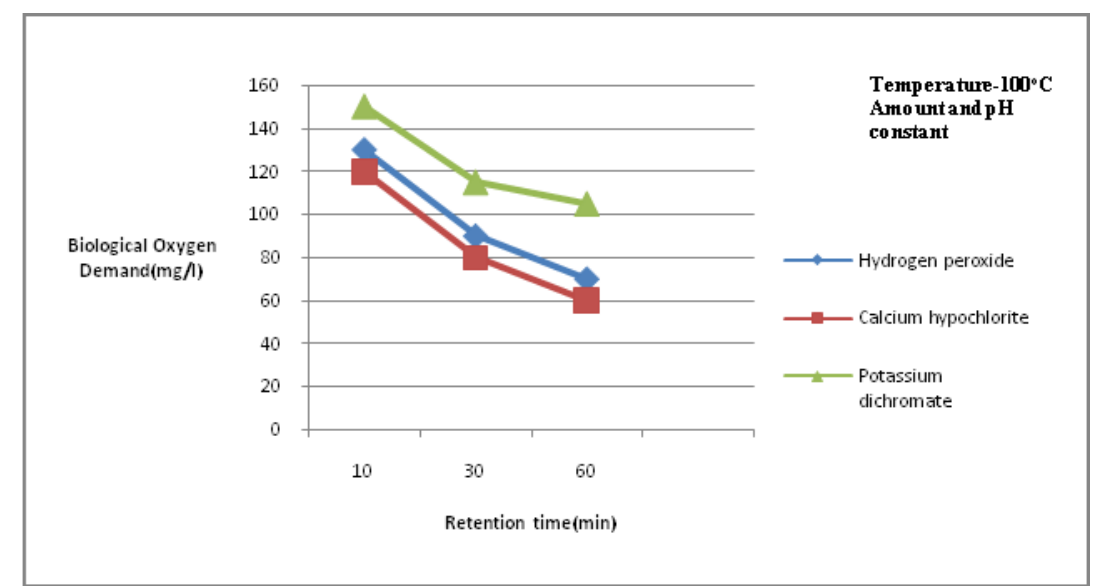

Fig. 6. Biological oxygen demand reduction at different retention time while temperature, amount and $\mathrm{pH}$ are constant ( $\mathrm{pH}-3$ to 6 , temperature $-100^{\circ} \mathrm{C}$, amount- $\left.100 \mathrm{mg} / \mathrm{l}\right)$

\subsection{Effect of amount of oxidants}

The effect on the amount of oxidants is shown in figure 7 to 9 , at constant temperature $(50 \mathrm{oC})$ and retention time (30 min) with the varied amount of oxidants. Removal of BOD increased in a dose of oxidants increased the optimum dose caused the substantial removal of the BOD, maximum BOD reduction observed at 300 to $400 \mathrm{mg} / \mathrm{l}$ for Calcium Hypochlorite

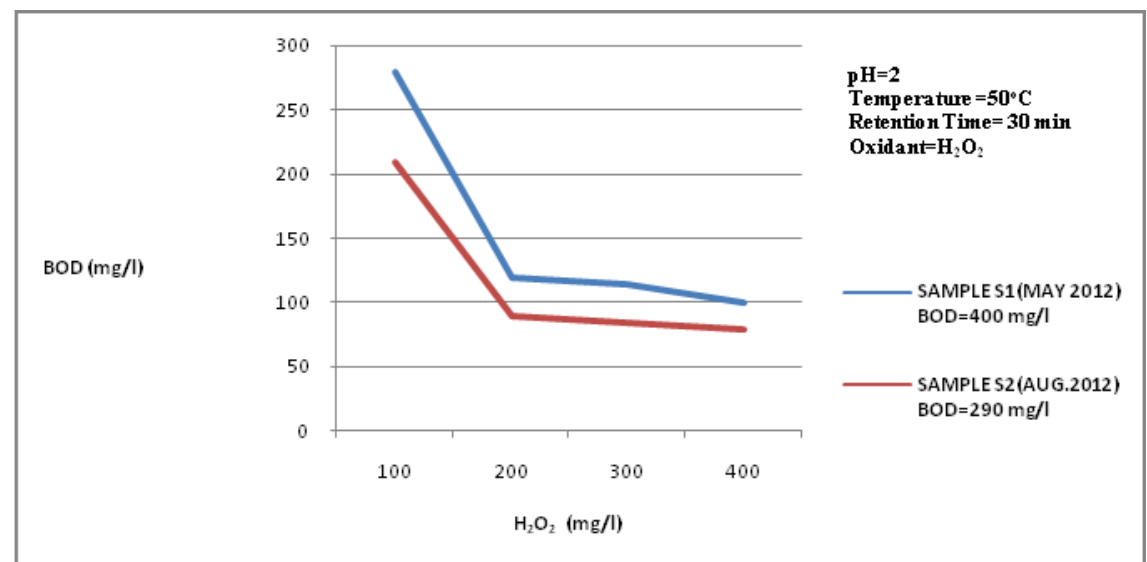

Fig. 7. $\mathrm{H}_{2} \mathrm{O}_{2}$ dosages effect on BOD reduction while other parameters ( $\mathrm{pH}$, retention time, temperature) are constant.

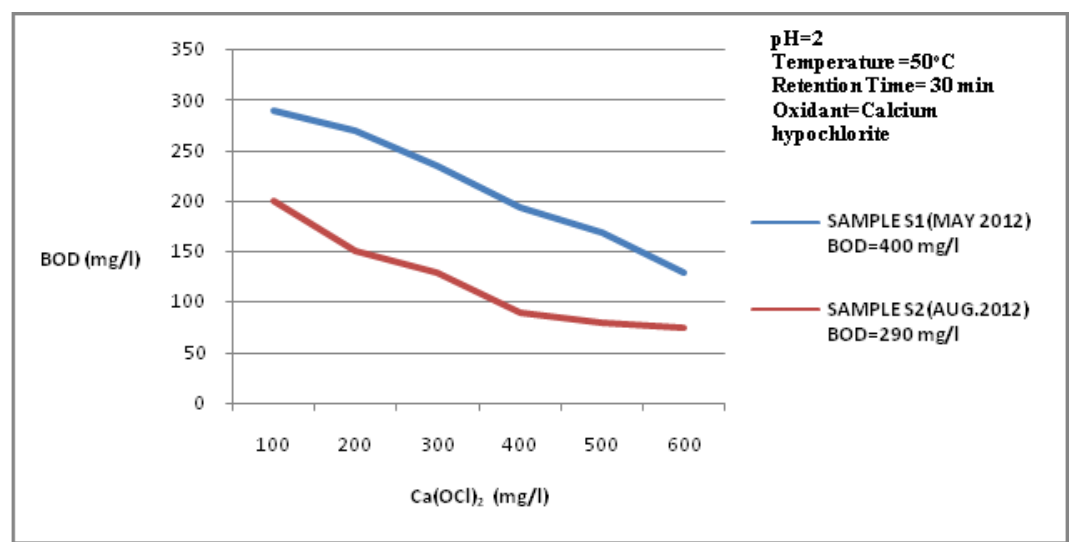

Fig. 8.Ca $(\mathrm{OCl})_{2}$ dosages effect on BOD reduction while other parameters ( $\mathrm{pH}$, retention time, temperature) are constant. 


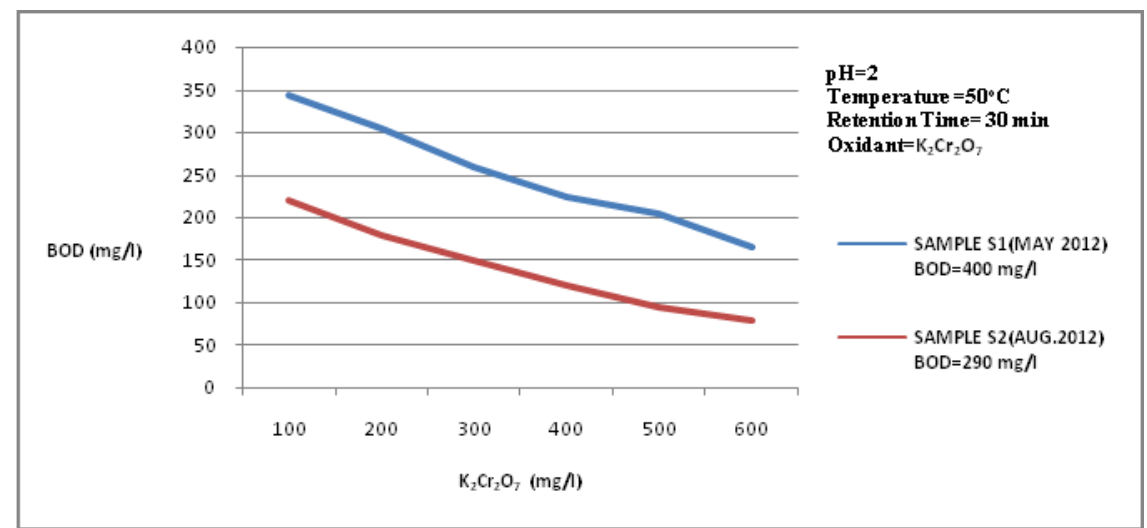

Fig. 9. $\mathrm{K}_{2} \mathrm{Cr}_{2} \mathrm{O}_{7}$ dosages effect on $\mathrm{BOD}$ reduction while other parameters (pH, retention time, temperature) are constant.

\subsection{Effect of $\mathrm{pH}$ on BOD reduction}

To determine the optimum $\mathrm{pH}, \mathrm{pH}$ was changed to 2-6 as shown in figure 9 at constant value of other variables (time, amount, temperature), the maximum BOD removal was observed at 4 for Hydrogen peroxide, 8 for Calcium Hypochlorite and Potassium dichromate.

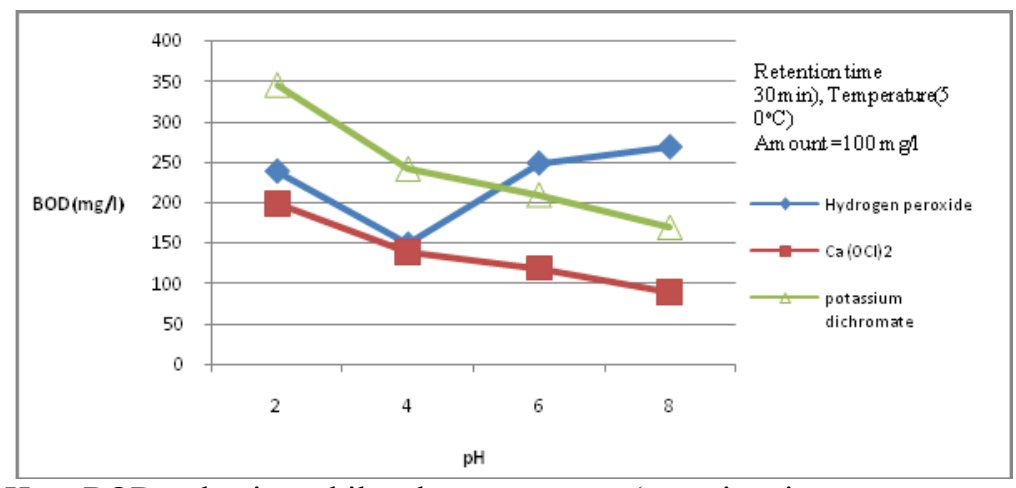

Fig.10.effect of $\mathrm{pH}$ on BOD reduction while other parameters (retention time, temperature, and amount) are constant.

\section{Conclusion}

In the present investigation the Sanganer area was surveyed to assess the problem of textile industry pollution. The optimal physiological conditions were determined at lab scale that can be further scaled up and used for effluent treatment at industry level. In this study reduction of BOD of textile effluent was studied using three oxidants Hydrogen Peroxide, Calcium Hypochlorite and Potassium Dichromate, and study of physicochemical analysis of sample soil and water , the important parameters for oxidation process by the oxidants are retention time, the amount of oxidants and $\mathrm{pH}$, results from the study show that following results:

1. Different samples of soils and water from the Sanganer area showed differences in the physico-chemical characteristics from one another with respect to chemical characteristics, as expected due to a relatively wide spectrum of dye manufacturing sources and due to presence of dyes and various types of organic and inorganic chemicals in the textile effluent.

2. The soil samples adjoining the textile effluent collected from agricultural region of Sanganer also showed great variation in the physico-chemical properties. The $\mathrm{pH}$ of the soil samples ranged from 7.6-9.2 and EC from $0.83-1.20 \mathrm{mmhos} / \mathrm{cm}$ and $\%$ organic matter $(\mathrm{OM})$ of the soil samples ranged from $0.40-2.02$. The $\mathrm{Cl}^{-}$ content in soil varied from $35-66 \mathrm{mg} / 100 \mathrm{~g}$ of soil.

3. The $\mathrm{pH}$ of the effluents ranged from 7.6-7.9, electrical conductivity (EC) from $3.5-4.55 \mathrm{mmhos} / \mathrm{cm}$ and temperature between $25.0-29.0^{\circ} \mathrm{C}$. Total dissolved solids were between $465-905 \mathrm{mg} / \mathrm{L}$. Cation $\left(\mathrm{Na}^{+}\right.$and $\mathrm{K}^{+}$) and anion $\left(\mathrm{Cl}^{-}\right)$concentration in the effluent also showed wide variation. The results exhibited that cations ranged from $\mathrm{Na}^{+}(216-595 \mathrm{mg} / \mathrm{L})$ and $\mathrm{K}^{+}(1.1-3.12 \mathrm{mg} / \mathrm{L})$ and $\mathrm{Cl}^{-}$ranged from $(105-285 \mathrm{mg} / \mathrm{L})$. The calcium hardness $(12-$ $36 \mathrm{mg} / \mathrm{L})$ and magnesium hardness $(18-38 \mathrm{mg} / \mathrm{L})$ also showed significant variation.

4. BOD concentration of discharge effluent in the drainage higher than the prescribed limit by PollutionControl Board, Rajasthan (India). 
5. When temperature increased than higher BOD reduction seen at lesser retention time, at 10 min retention time, $100^{\circ} \mathrm{C}$ BOD reduction similar to $50^{\circ} \mathrm{C}$ at 60 minute retention time.

6. Calcium hypochlorite reduced maximum $\mathrm{BOD}$ at given temperature and retention time compare to others due to availability of two $\left(\mathrm{OCl}^{-}\right)$per formula of $\mathrm{Ca}(\mathrm{OCl})_{2}$ for oxidation.

7. Optimum $\mathrm{pH}$, temperature and amount for Calcium hypochlorite are $4,100^{\circ} \mathrm{C}$, and $300-500 \mathrm{mg} / 1$ respectively.

The results obtained this study are expected to contribute to control the textile industry, Wastewater pollution and to protect aquatic environment.

\section{Acknowledgment}

Special thanks to the Honorable Chancellor Mr. Sandeep Bakshi, Jaipur National University as well as the Principal Prof.S.k Gupta of School of Engineering and Technology, Jaipur National University for their motivation and financial support.

\section{References}

[1] APHA (1992) Standard methods for the examination of water and waste water, American Public Health Association (18 ${ }^{\text {th }}$ Ed) Academic Press, Washington DC, 214- 218.

[2] Aslam et al. EJEAFChe, 3 (6), 2004. "Textile waste water characterization and reduction of its COD and BOD by oxidation".

[3] Barclay, S. and Buckley, C. 2000. Waste Minimization Guide for the Textile Industry, A Step towards Cleaner Production (Volume 1), by The Pollution Research Group University of Natal Durban South Africa, The South African Water Research Com., January, 92 pp.

[4] Baslas RK, Singh S (1984) Chemical studies on effluent of textile industries to check the various diseases in human beings. Indian $J$ Phyl Nat Sci 4:18-21.

[5] Cláudia Telles Benatti and Célia Regina Granhen Tavares, Fenton's Process for the Treatment of Mixed Waste Chemicals, in Dr. Tomasz Puzyn (Ed.), Organic Pollutants Ten Years After the Stockholm Convention - Environmental and Analytical Update, (InTech, 2012) 247-270.

[6] E. Greenberg, L.S. Clesceri, A.D. Eaton, Standard methods for the examination of water and wastewater, 18th Edition; 5 (1992) 610 .

[7] F. Vaezi, K. Naddafi, F. Karimi and M. Alimohammadi, Application of chlorine dioxide for secondary effluent polishing, International Journal of Environmental Science \& Technology, 1(2), 2004, 97-101.

[8] Jiunkins R (1982) Pretreatment of textile waste water. Proc. 37 ${ }^{\text {th }}$ Industrial waste Conference Purdue Uni. Lafayette, $137-139$.

[9] Khan TI, Kaur N, Vyas PC (1995) Effect of industrial effluents on physicochemical characteristics of Amaanishahnallah- a case study. J Environ Pollut, 2:147-150.

[10] Lech Kos, Karina Michalska and Jan Perkowski, Textile Wastewater Treatment by the Fenton Method, Fibres \& Textiles in Eastern Europe, 18 (4), 2010, 105-109.

[11] Manivasakam N (1987) Industrial Effluent: origin, characteristics, effects, analysis and treatment. Shakti Publication, Coimbatore, India. 60-78.

[12] Metcalf and Eddy, Wastewater Engineering: Treatment and Reuse (Tata McGraw-Hill, Fourth edition, 2003).

[13] M. Ali Awan, Reduction of chemical oxygen demand from Tannery wastewater by oxidation, Electronic Journal of Environmental, Agricultural and Food Chemistry 3(1), 2004, 625-628.

[14] N. Tüfekçi et al. / Turk. J. Fish. Aquat. Sci. 7: 97-103 (2007) "Pollutants of Textile Industry Wastewater and Assessment of its Discharge Limits by Water Quality Standards"

[15] Putri F. Khamaruddin, M. Azmi Bustam and A. Aziz Omar, Using Fenton's Reagents for the Degradation of Diisopropanolamine: Effect of Temperature and $\mathrm{pH}$, International Conference on Environment and Industrial Innovation IPCBEE 12, Singapore, 2011, $12-17$.

[16] Qingxuan Zhang and Guohua Yang, The removal of COD from refinery wastewater by Fenton reagent, IEEE Conference (RSETE), China, 2011, $7974-7977$.

[17] Rai H, Bhattacharya M, Singh J, Bansal TK, Vats P, Banerjee UC (2005) Removal of dyes from the effluent of textile and dyestu ff manufacturing industry; Emerging techniques with reference to biological treatment: a review. Environ Sci Technol, 35: 219-238.

[18] Ramsay J, Nguyen T (2002) Decoloration of textile dyes by Trametes versicolor and its effect on dye toxicity. Biotechnol Lett, 24: $1757-1761$.

[19] RSPCB 2012. Discharge Standards for Sewere System Discharges for Industrial Wastewaters, The Official State Bulletin, and schedule-1 (rule-3), Rajasthan.

[20] Sharma KP, Sharma K, Bharadwaj M, Chaturvedi RK, Subhasini (1999) Environment impact assessment of textile printing industries in Sanganer, Jaipur: A case study. J Indian Bot Soc, 78:71-85.

[21] Singh Vijendra and C.P. Singh Chandel (2006): Analysis of Wastewater of Jaipur City for Agricultural Use. - Research Journal of Chemistry and Environment. 10(1): 30-33.

[22] Sreeram, K, J, et al. (1998) "use of Hydrogen Peroxide for Tannery Wastewater Treatment" journal of Scientific \& Industrial Research; 57, 64-69.

[23] Tatawat - Singh Chandel (2007) "'Quality of ground water of Jaipur city and its suitability for domestic and irrigation purpose" Applied ecology and environmental 6(2): 79-88.

[24] Young, j.c., g.n. Mcdermott\& d. Jenkins. 1981. Alterations in the BOD procedure for the 15th edition of Standard Methods for the Examination of Water and Wastewater. J. Water Pollut. Control Fed. 53:1253. 